\title{
Effect of appendicularians and copepods on bacterioplankton composition and growth in the English Channel
}

\author{
Mikhail V. Zubkov ${ }^{1, *}$, Angel López-Urrutia ${ }^{2}$ \\ ${ }^{1}$ George Deacon Division for Ocean Processes, Southampton Oceanography Centre, University of Southampton, \\ Empress Dock, Southampton SO14 3ZH, United Kingdom \\ ${ }^{2}$ Plymouth Marine Laboratory, Prospect Place, Plymouth PL1 3DH, United Kingdom
}

\begin{abstract}
We compared the effects of the presence of the appendicularian Oikopleura dioica and the copepods Acartia clausii and Calanus helgolandicus on the coastal bacterioplankton community off Plymouth. Mesozooplankton were added to water samples and bacterioplankton growth was monitored by flow cytometry. Phylogenetic composition of bacterioplankton was analysed using fluorescence in situ hybridisation (FISH) with rRNA-targeted oligonucleotide probes. The bacterioplankton composition did not change in the presence of either appendicularians or copepods, and generally the same proportions of bacterioplankton groups were determined. In late spring, $15 \pm 2 \%$ of cells hybridised with a probe specific to the Kingdom Archaea. The majority of cells ( $88 \pm 2 \%)$ belonged to the Kingdom Bacteria, and $86 \%$ of cells were identified using group-specific probes. The Cytophage-Flavobacterium cluster dominated the community, comprising $64 \pm 0.5 \%$ of cells. The $\gamma$ proteobacteria were the second abundant group, comprising $11 \pm 0.5 \%$ of cells, and the SAR86 cluster of $\gamma$-proteobacteria accounted for $6 \pm 5 \%$. The $\alpha$-proteobacteria comprised $10 \pm 5 \%$ of bacterioplankton, and the Roseobacteria related cluster represented $9 \pm 3 \%$ of cells. The reduction of bacterioplankton growth caused by appendicularian bacterivory was 0.4 to $14 \%$ ind. $^{-1} \mathrm{l}^{-1}$, and the total appendicularian population could reduce bacterial growth in coastal waters in late springsummer by up to $9 \%$. In contrast to the appendicularians the copepods stimulated bacterial growth, and in summer the bacterioplankton growth may be increased by up to $13 \%$ by the combined effect of dominant copepod populations. Thus, the appendicularians and copepods had an opposite but moderate effect on the bacterioplankton growth and no effect on the bacterioplankton composition.
\end{abstract}

KEY WORDS: Community structure - Zooplankton · FISH $\cdot$ Flow cytometry $\cdot$ Bacterial production · Nutrient bioavailability

Resale or republication not permitted without written consent of the publisher

\section{INTRODUCTION}

Copepods, Cladocerans and Tunicates are the 3 major mesozooplankton groups in aquatic pelagic ecosystems (Sommer \& Stibor 2002). All mesozooplankton groups can increase bacterial growth by producing nutrients through sloppy feeding, excretion and leakage from fecal pellets (e.g. Roman et al. 1988, Jurgens et al. 1994, Hygum et al. 1997, Moller \& Nielsen 2001, Katechakis et al. 2002). Cladocerans are usually the dominant group in limnic environments, where they regulate bacterioplankton communities either directly by feeding on bacteria (e.g. Langenheder \& Jurgens 2001) and/or indirectly by consuming bacterivorous protists.

The way in which changes in the mesozooplankton community affect bacterioplankton in marine ecosystems is still poorly understood. The transfer efficiencies of bacterial carbon to marine mesozooplankton are lower in the community dominated by copepods and increase when pelagic tunicates are more abundant (Koshikawa et al. 1996, 1999). Pelagic tunicates (i.e. appendicularians, salps, doliolids and pirosomids) feed on both bacteria and their protist predators (e.g. 
King et al. 1980, Sommer \& Stibor 2002). Considering appendicularians to be size selective grazers, because their retention efficiency of artificial beads decreases rapidly with particle diameters < $0.5 \mu \mathrm{m}$ (Bedo et al. 1993), one may speculate that they affect bacterial community composition. Compared to tunicates and cladocerans, adult copepods do not feed on bacteria but may exert an indirect influence on bacterial communities by consuming bacterial predators.

The aim of the present study was a direct comparison of the effect of appendicularians and copepods on the natural bacterioplankton community through the spring-summer seasonal succession. We hypothesised that mesozooplankton may influence bacterial community composition by affecting either production or loss of bacterioplankton, changes in either of which can be associated with changes in bacterial community composition (Simek et al. 2002). Using incubation experiments, we examined changes of bacterioplankton composition and growth in the presence or absence of 1 species of appendicularians and 2 species of copepods.

\section{MATERIALS AND METHODS}

Study site and experimental design. Samples of seawater and copepods were collected in the English Channel $18 \mathrm{~km}$ southwest of Plymouth (Stn L4, see www.pml.ac.uk/L4) in May-July 2001 and 2002. The appendicularian Oikopleura dioica, and the copepods Calanus helgolandicus and Acartia clausii were used in the experiments. Because we were not comparing different metazoan species of the same genus, we generally use genus names from this point in the text to simplify data presentation.

Calanus freshly collected at Stn L4 (assumed to be fed - ' $F^{\prime}$ ) or starved in the laboratory ('S') were used to determine whether the physiological state of Calanus has an effect on bacterioplankton. Sample F copepods were collected, concurrently with seawater, using a standard WP-2 net. Sample S Calanus were grown in laboratory culture and starved by incubating in $0.2 \mu \mathrm{m}$ filtered water for $24 \mathrm{~h}$ before the start of the experiments. Oikopleura cultures were maintained in $30 \mu \mathrm{m}$ filtered seawater from Stn L4. The cultures were continuously agitated by means of an acrylic paddle rotating at $10 \mathrm{rpm}$ (Fenaux \& Gorsky 1985). Four hours before setting up an experiment, the animals were transferred in 2 consecutive steps into beakers containing water identical to that used for the experiment. This reduced contamination with bacteria present in cultures and allowed the appendicularians to secrete a new house.

The experiments were conducted in a room of constant temperature at $15^{\circ} \mathrm{C}$, with a simulated day/night cycle (12 h light and $12 \mathrm{~h}$ dark) using cool fluorescence lamps. We used 2 different types of incubation vessels: half-filled 21 glass beakers continuously agitated by means of a paddle (10 rpm), and 11 glass bottles mounted on a plankton wheel (1 rpm). The bottles, beakers and carboys used in experiments were extensively washed with $1 \mathrm{~N} \mathrm{HCl}$ acid and rinsed with sterile seawater, freshly filtered through $0.2 \mu \mathrm{m}$ Nuclepore filters. The micro- and mesozooplankton present in the natural seawater used for the experiments were removed by screening through a $20 \mu \mathrm{m}$ mesh. Five adult Calanus, 15 Acartia, or 15 to 75 Oikopleura were transferred into each 11 vessel, in 2 to 4 replicates. Vessels left without metazoans were used as a control. The survival among metazoans during the first $2 \mathrm{~d}$ was 93 to $100 \%$. Water samples for enumeration of bacterioplankton were taken every 2 to $8 \mathrm{~h}$ for 1 to $4 \mathrm{~d}$. Every 2 to $8 \mathrm{~h}$, water samples were taken for enumeration of bacterioplankton; $2 \times 1 \mathrm{ml}$ subsamples were mixed in a cryovial, fixed with $1 \%$ paraformaldehyde for $24 \mathrm{~h}$ at $2{ }^{\circ} \mathrm{C}$ and stored frozen at $-20^{\circ} \mathrm{C}$.

In order to separate a trophic cascade effect from a zooplankton excretion effect on bacterioplankton, an additional experiment was done with summer bacterioplankton. Bottles were either filled as usual with the $20 \mu \mathrm{m}$ filtered seawater to maintain nanoplankton (NPL) including protozoan bacterivors (nanoplankton present: NPL+) or with water gently filtered through a GF/A glass fibre filter to remove nanoplankton (nanoplankton absent: NPL-). The GF/A filters were replaced after filtering 11 of water to reduce nutrient enrichment from retained damaged organisms.

Enumeration of organisms. Bacterioplankton and small particles $<0.2 \mu \mathrm{m}$ size were enumerated in either freshly fixed samples or in thawed frozen samples, after staining with SYBR ${ }^{\circledR}$ Green I (Marie et al. 1997). The particles were counted using a flow cytometer (FACSort) as described previously (Zubkov et al. 2001c). A photomultiplier tube was used for improving sensitivity of the forward scatter (FSC) detection, and the FSC measurements were used as proxies of bacterial cellular biomass (Robertson et al. 1998). Yellow-green fluorescent beads, $0.5 \mu \mathrm{m}$ diameter (Polysciences), were used as an internal standard to compute the absolute concentration of microbes. The absolute concentration of beads was determined by flow cytometric counting of beads in volumes dispensed with an automatic micro-injector (KD Scientific).

Fluorescence in situ hybridisation. Using the flow cytometric data, samples representing bacterioplankton in mid-exponential growth phase were selected for fluorescence in situ hybridisation (FISH) analysis (Glöckner et al. 1996, Fuchs et al. 2000b). Cells present in $50 \mu \mathrm{l}$ of fixed samples were collected on pieces of $0.2 \mu \mathrm{m}$ polycarbonate filter. Oligonucleotide probes for the following 
prokaryotic groups were used: GMP1242 (Zubkov et al. 2001a), specific for the SAR86 cluster of $\gamma$-proteobacteria (Mullins et al. 1995); RSB67 (Zubkov et al. 2001a), specific for the $\alpha$-proteobacterial genus Roseobacter; CF319a (Manz et al. 1996), specific for CytophagaFlavobacterium (CF) cluster; ALF968, specific for the $\alpha$ subclass of Proteobacteria; GAM42a, specific for $\gamma$ subclass of Proteobacteria; EUB338 (Amann et al. 1990), specific for the Kingdom Bacteria; and ARCH915 (Stahl \& Amann 1991), specific for the Kingdom Archaea. Probes labelled with fluorescence indocarbocyanine dye CY3 and unlabelled helper oligonucleotides (Fuchs et al. 2000a) were synthesised commercially (Sigma-Genosys). Cells were viewed using an Axioscop 2 epifluorescence microscope equipped with a $100 \times$ Plan Apochromat objective (Zeiss, Germany). Probe positive cells were presented as percentages of cells stained with a general nucleic acid dye, DAPI, and at least 300 cells were counted per filter.

Statistical analysis. Acquisition and preliminary analysis of flow cytometric data was done using CellQuest software (Becton Dickinson). Specific growth rates of bacterioplankton were calculated using exponential approximation of the increase of cell concentration with time (regression coefficient, $\mathrm{r}^{2}=0.95$ to 0.997 , $\mathrm{p}<0.001$ ), excluding a lag phase of about $15 \mathrm{~h}$. The values of the parameters are given as the mean of 2 to 4 replicates, error bars on figures indicate single standard deviations. A regression analysis and $t$-test were used for comparison of the data sets.

\section{RESULTS}

The plankton wheel and the paddle stirring systems produced remarkably consistent results, i.e. very small standard deviations of replicates (Fig. 1). The bacterial counts were virtually the same in both types of vessels (Fig. 1a), and the computed specific growth rates were very similar. Plotted against each other they were within an error margin from the unity line (Fig. 1b).

\section{Effect of appendicularians on bacterioplankton growth and composition}

The presence of Oikopleura in spring, when bacterioplankton growth rate was the highest at ca. $3 \mathrm{~d}^{-1}$, resulted in a small, although statistically significant, reduction of bacterial growth by $0.4 \%$ ind..$^{-1} \mathrm{l}^{-1}$ (Fig. 1a). In late spring when bacteria growth rate decreased to $1.2 \mathrm{~d}^{-1}$ (Fig. 2), Oikopleura consumed a considerable proportion of bacteria, reducing bacterial growth rate by $3 \pm 1 \%$ ind..$^{-1} \mathrm{l}^{-1}$ (Fig. 2a) and up to $14 \%$ ind..$^{-1} \mathrm{l}^{-1}$ in the short experiment with 75 ind. $\mathrm{l}^{-1}$. In addition to
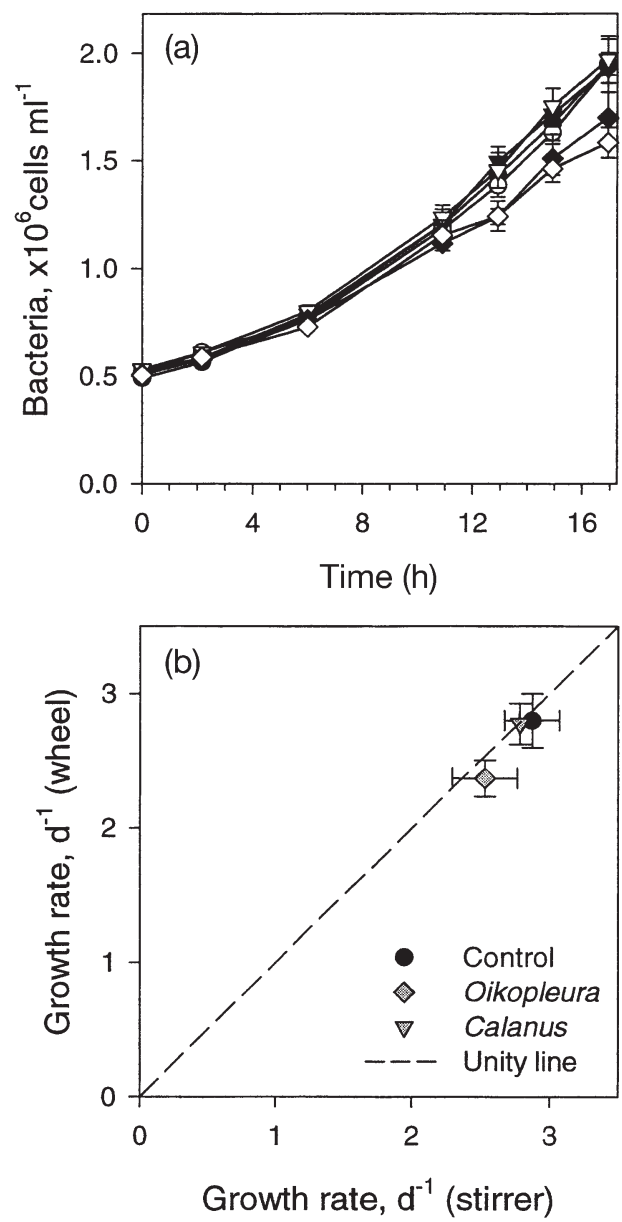

Fig. 1. Comparison of (a) growth of spring blooming bacterioplankton and (b) computed growth rates in the absence (control) and presence of Oikopleura dioica and Calanus helgolandicus in 2 incubation systems: beakers stirred with paddles (stirrer, filled symbols in a) and bottles mounted on a plankton wheel (wheel, open symbols in a). Symbols show mean values $\pm 1 \mathrm{SD}$; small error bars are obscured by symbols

grazing on bacteria, appendicularians also consumed particles less than $0.2 \mu \mathrm{m}$ in size (Fig. 2b).

There seemed to be no direct selectivity in Oikopleura feeding on bacterioplankton as the bacterioplankton community composition did not change significantly in the short experiment (Fig. 3a). Only $15 \pm$ $2 \%$ of cells hybridised with a probe specific to the Kingdom Archaea. The majority of cells $(88 \pm 2 \%)$ belonged to the Kingdom Bacteria. The group specific probes allowed a coarse phylogenetic affiliation of $86 \pm$ $7 \%$ of picoplanktonic cells. The CF cluster dominated the community, comprising $64 \pm 0.5 \%$ of cells, followed by the $\gamma$-proteobacteria, which represented $11 \pm 0.5 \%$ of cells. This community structure is characteristic for marine bacterioplankton in general (e.g. Glöckner et al. 1999, Simon et al. 1999) and for bacterioplankton in the English Channel in particular (Fuchs et al. 2000b). 

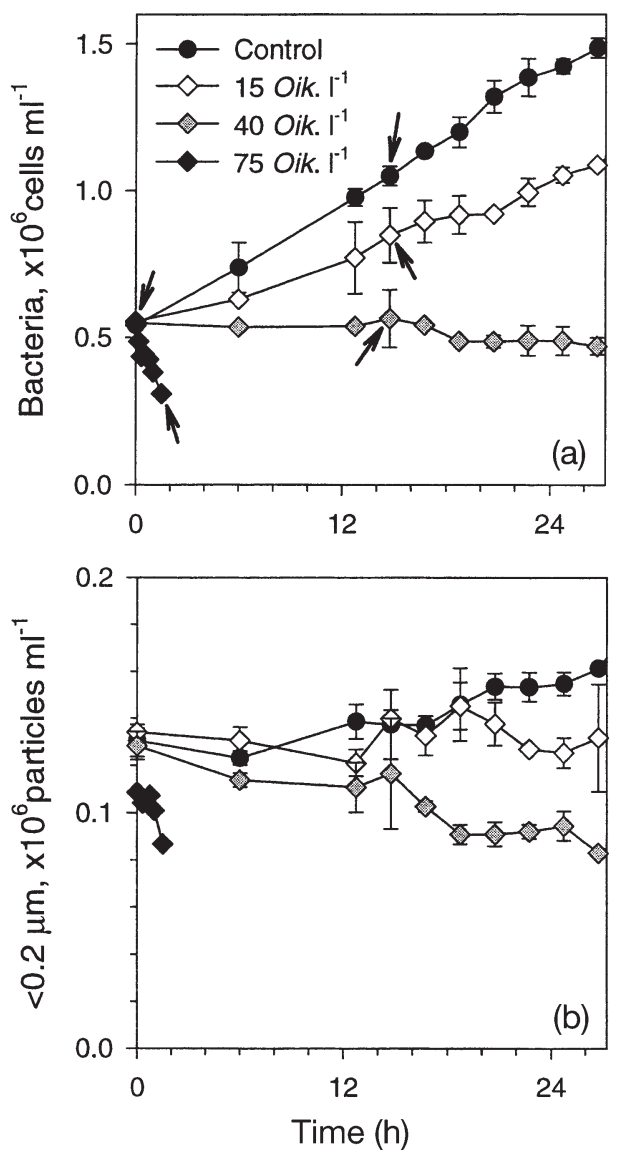

Fig. 2. (a) Growth of late spring bacterioplankton, specific growth rate $1.2 \mathrm{~d}^{-1}$, and (b) dynamics of $<0.2 \mu \mathrm{m}$ particles in the absence (control) and presence of Oikopleura dioica (Oik.) at different concentrations. Arrows indicate samples used for FISH analysis, the results of which are presented in Fig. 3. Symbols show mean values $\pm 1 \mathrm{SD}$; small error bars are obscured by symbols

The probe CF319a targeted a fairly large phylogenetic group, and therefore, we cannot exclude potential variability within the CF cluster. A more detailed phylogenetic affiliation of bacteria was attempted using the probe RSB67, specific to the Roseobacter genus, which has been found to be an abundant and ecologically important bacterioplankton component in the Celtic and North Seas (Zubkov et al. 2001a,b). The genus represented almost all $\alpha$-proteobacteria, which comprised $10 \pm 5 \%$ bacterioplankton, and the Roseobacteria related genus represented $9 \pm 3 \%$ of cells. The other ecologically important photoheterotrophic SAR86 cluster of $\gamma$ proteobacteria (Kolber et al. 2001) accounted for $6 \pm 5 \%$ of all bacteria. But Roseobacter, SAR86 clusters, and the bacterioplankton community in general did not appear to be sensitive to the presence of Oikopleura.

In the long experiment (Fig. 2a), the composition of bacterioplankton grown under the feeding pressure of
Oikopleura compared to the control showed only limited changes (Fig. 3b). The CF cluster comprised $70 \pm$ $1 \%$ of cells in the experiment compared to $46 \%$ in the control. However, because we could affiliate $105 \pm$ $4 \%$ and $78 \%$ of bacteria in the experiment and control, respectively, we could not exclude the possibility that the difference might also be a result of less efficient hybridisation of slower growing CF cells in the control.
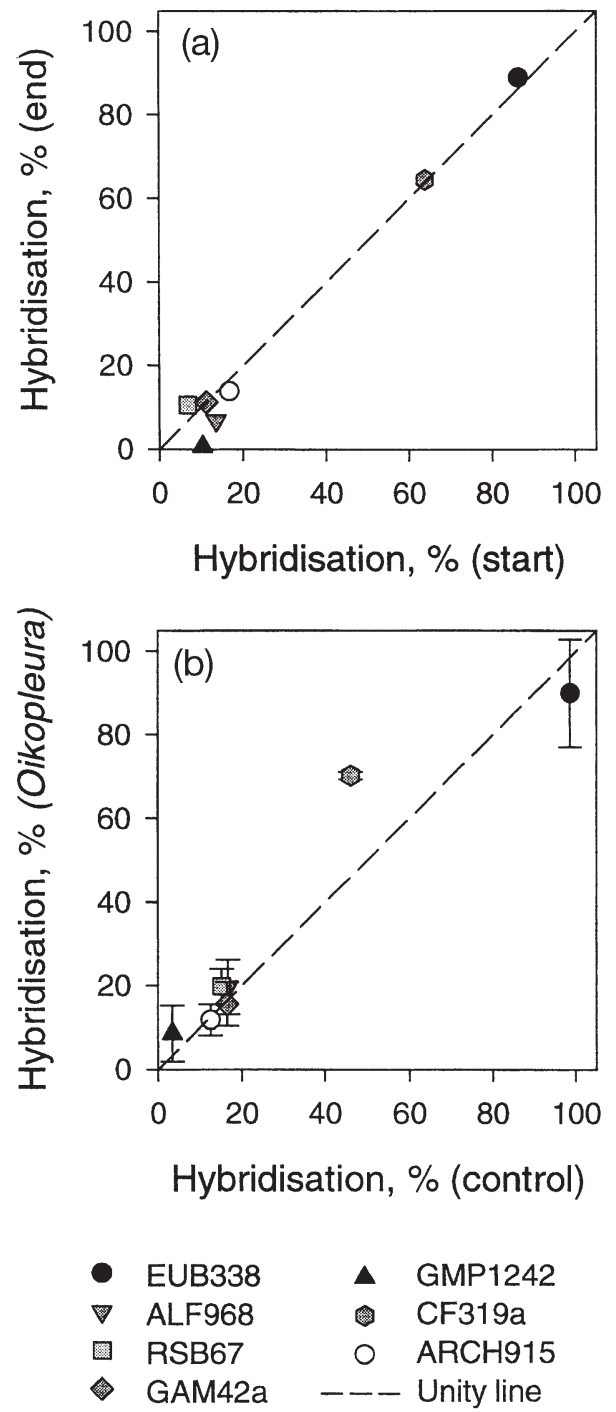

Fig. 3. Comparison of bacterioplankton community composition (a) at the start and at the end of the short experiment with 75 Oikopleura dioica, and (b) in the absence (control) and presence of $O$. dioica in the long experiment. The probes used were as follows: EUB338 for Bacteria, ALF968 for $\alpha$ proteobacteria, RSB67 for the Roseobacter genus, GAM42a for $\gamma$-proteobacteria, GMP1242 for the SAR86 cluster of $\gamma$ proteobacteria, CF319a for the Cytophaga-Flavobacterium cluster and ARCH915 for Archaea. Symbols show mean values $\pm 1 \mathrm{SD}$; small error bars are obscured by symbols 


\section{Comparison of copepod effects on bacterioplankton growth and composition}

At the peak of bacterial growth, the presence of Calanus had no effect on bacterioplankton (Fig. 1). However, when bacterioplankton were growing more slowly (specific growth rate of about $2 \mathrm{~d}^{-1}$ ), Calanus was associated with a significant increase in bacterial growth rates (Fig. 4a). The bacterial growth rates, significantly different, were 6.3 and $4.8 \%$ ind. $^{-1} \mathrm{l}^{-1}$ higher than in the control, respectively in the presence of fed and starved Calanus specimens.

The effect of Acartia and Calanus presence was compared in summer when bacterioplankton grew slower possibly due to nutrient limitation (specific growth rate $0.6 \mathrm{~d}^{-1}$ ). To compare the indirect trophic cascade effect of copepods on bacterioplankton growth, i.e. consumption of bacterivorous protists, and the direct effect of copepod excretion, the experiments were done in parallel in the presence and absence of nanoplankton (Fig. 5a,b). To minimise cell damage and consequently artificial nutrient enrichment, glass fibre filters were chosen for screening nanoplankton (nanoplankton absent: NPL-). Apart from nanoplankton, the filters retained $34 \pm 3 \%(n=10)$ of bacterial

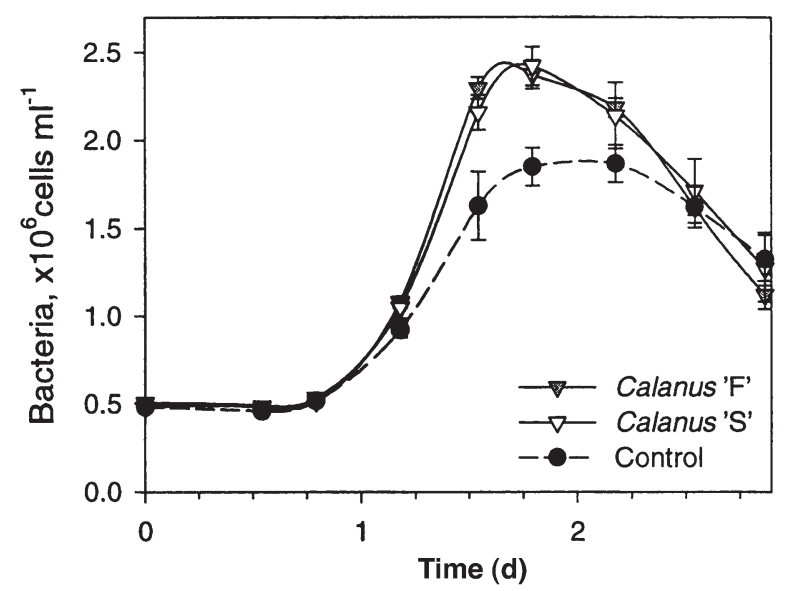

Fig. 4. Growth of late spring bacterioplankton, specific growth rate $2 \mathrm{~d}^{-1}$, in the absence (control) and presence of Calanus helgolandicus in 2 physiological states: fed (F) and starved (S). Symbols show mean values $\pm 1 \mathrm{SD}$; small error bars are obscured by symbols

cells (Fig. 5a,b) and also reduced average bacterium biomass by $30 \pm 5 \%$ by selective retention of bigger cells (Fig. $5 \mathrm{c}, \mathrm{d}$ ). Therefore more nutrients were made available per bacterium and, consequently, growth
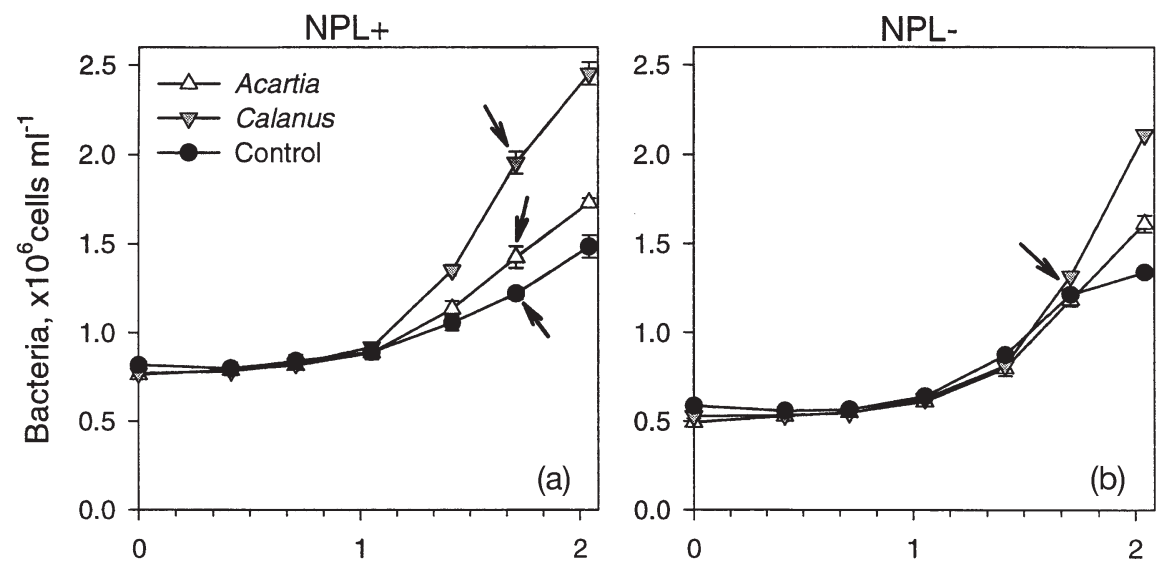

Fig. 5. Dynamics of summer bacterioplankton $(\mathrm{a}, \mathrm{b})$, bacterial forward light scatter (FSC) - a proxy of cellular biomass $(\mathrm{c}, \mathrm{d})$, and computed growth rates (e) in the presence of nanoplankton (NPL+, left column) and in the absence of nanoplankton (NPL-, right column), in the absence (control) and presence of copepods: Acartia clausii or Calanus helgolandicus. The dashed and solid lines are the unity line and regression line, respectively. Arrows indicate samples used for FISH analysis, the results of which are presented in Fig. 6. Symbols show mean values $\pm 1 \mathrm{SD}_{\text {; }}$ small error bars are obscured by symbols

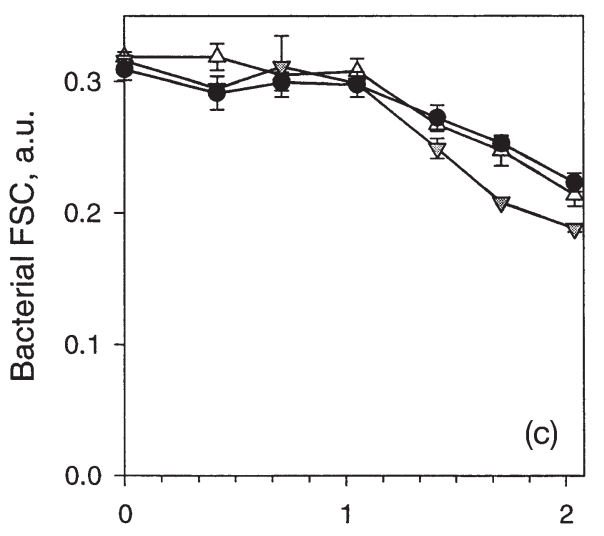

Time (h)

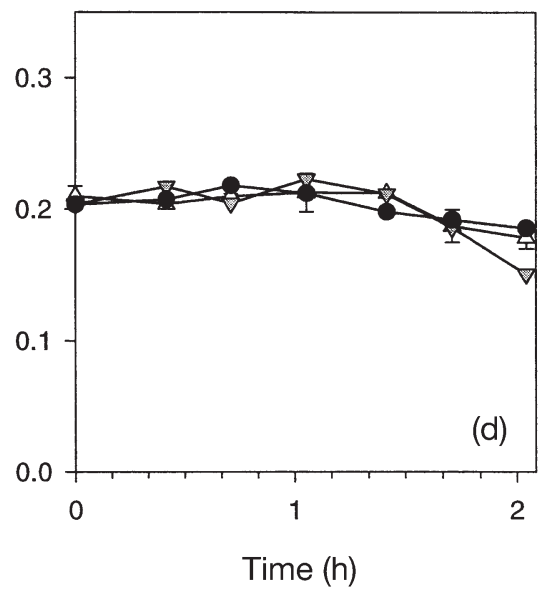

Time (h)

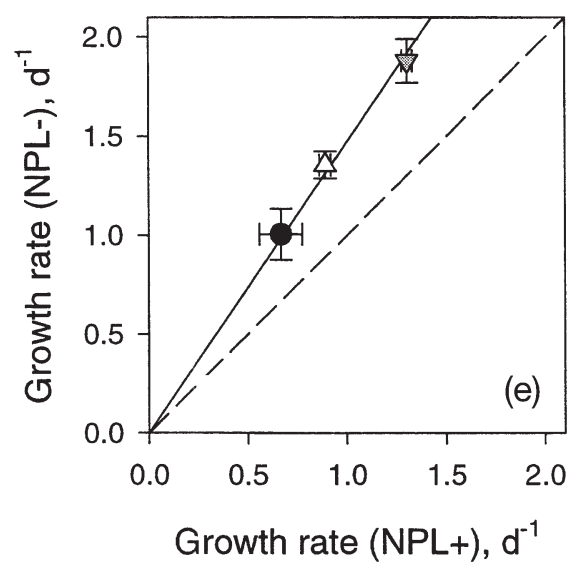


rates of bacteria increased proportionally. Bacterioplankton grew about 1.5 times faster in the NPL- treatment than in the NPL+ treatment (Fig. 5e); the cells remained smaller in the NPL- but they did not decrease in size as much as in the NPL+ (Fig. 5c,d).

In the presence of Calanus, bacterioplankton growth rates were $27 \%$ ind. ${ }^{-1} \mathrm{l}^{-1}$ higher than in the controls for the NPL+ treatment and $18 \%$ for the NPL- treatment. This increase in numerical growth was accompanied

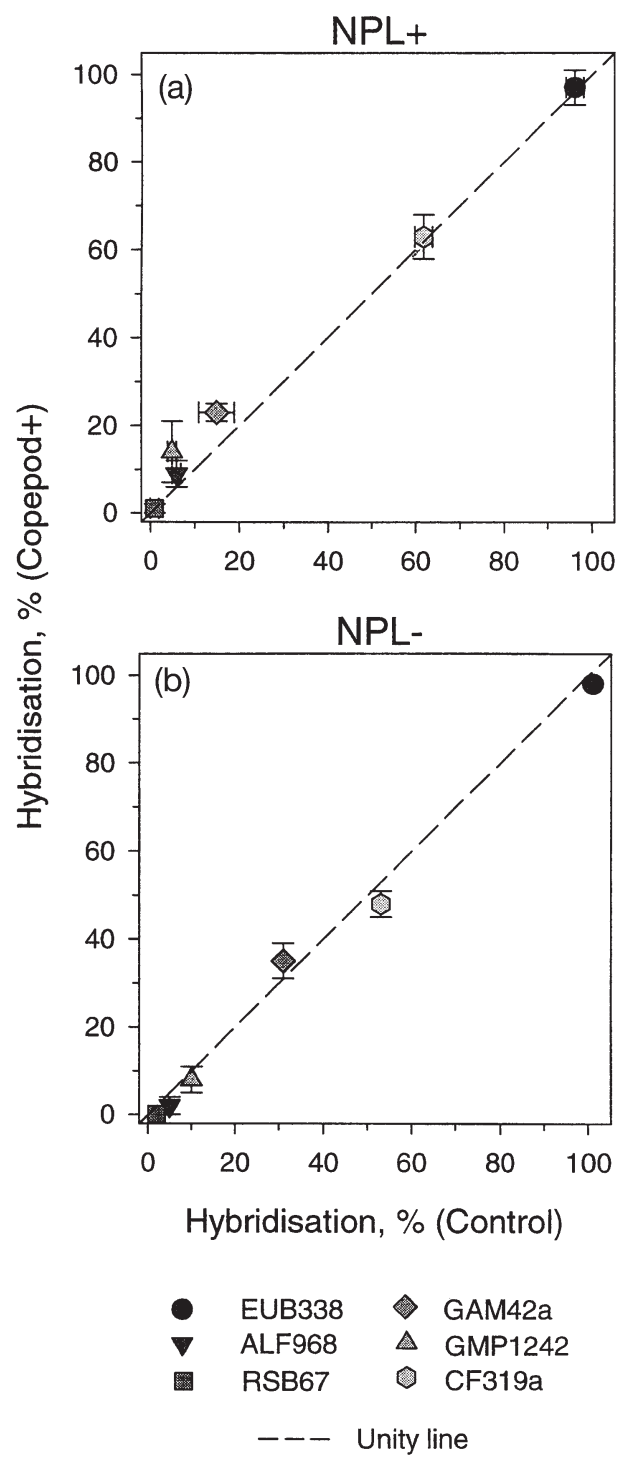

Fig. 6. Comparison of community composition of growing bacterioplankton in (a) NPL+ and (b) NPL- treatments in the absence (control) and presence of copepods. The probes used were as follows: EUB338 for Bacteria, ALF968 for $\alpha$-proteobacteria, RSB67 for the Roseobacter genus, GAM42a for $\gamma$ proteobacteria, GMP1242 for the SAR86 cluster of $\gamma$-proteobacteria, CF319a for the Cytophaga-Flavobacterium cluster. Symbols show mean values $\pm 1 \mathrm{SD}$; small error bars are obscured by symbols by a reduction in cellular biomass (Fig. 5c,d). The presence of Acartia was associated with increases in bacterial growth to a lesser extent, on $4 \%$ and $2.3 \%$ ind. $^{-1} \mathrm{l}^{-1}$, respectively for the NPL+ and NPLtreatments.

In the NPL+ treatments the composition of bacterioplankton in the presence of copepods and in the control was similar (Fig. 6a; small error bars indicate low variance). The majority of bacterial cells (97 $\pm 2 \%$ ) belonged to the Kingdom Bacteria and $87 \pm 7 \%$ of cells were identified using group specific probes. The CF cluster dominated the community comprising about $60 \%$ of cells. The $\alpha$-proteobacteria comprised $7 \pm 2 \%$ of bacterioplankton, and the Roseobacteria related genus represented only $1 \%$ of cells in the summer community. The $\gamma$-proteobacteria comprised $18 \pm 5 \%$ of cells, and the SAR86 cluster of $\gamma$-proteobacteria accounted for $9 \pm 6 \%$.

The presence of either copepod species had little effect on the composition of the bacterioplankton community in the absence of nanoplankton. However, because of the effects of filtering, the composition of bacterioplankton in the NPL- differed somewhat from the composition of bacteria grown in the NPL+ (Fig. 6a,b). The majority of cells, $99 \pm 3 \%$, were Bacteria and $86 \pm 7 \%$ of cells were identifiable by one of the group-specific probes. The CF cluster still dominated the community in the control as well as in the presence of copepods, but the CF cluster comprised only $50 \pm$ $4 \%$ of cells, and the $\gamma$-proteobacteria proportion rose to $34 \pm 4 \%$. The SAR86 cluster was the most conservative of the bacterial groups studied, comprising $9 \pm 2 \%$.

\section{DISCUSSION}

Marine bacterioplankton communities are controlled by nutrients (Ducklow 2000), protist predation (e.g. del Giorgio et al. 1996, Pernthaler et al. 1997, Jurgens et al. 1999, Zubkov et al. 2000) and viral infections (Fuhrman 1999). The presence of copepods, predators of bacterivors, can increase bacterial abundance and growth (e.g. Moller \& Nielsen 2001, Maar et al. 2002), while appendicularians can prey directly on bacteria (King et al. 1980, authors' unpubl. data) and therefore reduce bacterioplankton stocks. Consequently, we expected to observe a decrease in natural bacterioplankton concentrations in the presence of appendicularians (Fig. 2), and an increase in bacteria growth rates when copepods were present (Figs. 4 \& 5).

We also expected to see a change in the bacterioplankton community composition due to selective filtering of larger bacteria by appendicularians, but Oikopleura did not affect bacterial community composition. One might only speculate that some selective 
removal of larger $\alpha$ - and $\gamma$-proteobacteria occurred (Fig. 3b); however, this could also be a result of less efficient hybridisation of slower-growing CF cells in the control. The lack of a detectable change under appendicularian grazing pressure, and the ability of Oikopleura to consume particles even $<0.2 \mu \mathrm{m}$, suggest that the particle-size retention efficiencies for artificial beads (e.g. Bedo et al. 1993) might not be directly applicable to natural particles. Possibly, the natural particles can adhere better than beads when concentrated in the filters of the Oikopleura house, which would modify their capture efficiency. Appendicularians capture particles by sieving them onto the pharyngeal filter mesh and by direct interception onto filter fibres (Acuña et al. 1996). Although modern particle capture models in appendicularians predict a size retention minimum for particles of about $0.1 \mu \mathrm{m}$, there is also recognition of a difficulty in predicting behaviour of such small particles that can be subjected to other forces (e.g. electrostatic), which may modify contact rates between particles and filter fibres (Acuña et al. 1996). Our experimental results (Fig. 2) support these theoretical difficulties and contradict the conclusions drawn from the aerosol models; that small bacteria and large viruses can experience a refuge from grazing by appendicularians (Acuña et al. 1996).

Similarly to appendicularians, copepods did not alter bacterioplankton composition. Although there is evidence that copepod nauplii can ingest bacteria (Roff et al. 1995), adult copepods are not efficient bacterivors. The presence of copepods significantly increased growth (Fig. 5) without changing bacterioplankton composition (Fig. 6). Because the growth was consistently 1.5 times higher in the absence than in the presence of nanoplankton, it was more likely copepod excretion rather than their sloppy feeding on protists (Moller \& Nielsen 2001) that supplied the bacterioplankton with nutrients.

Bacterioplankton growth rate decreased and relative stimulation of bacterioplankton growth by copepods increased from spring to summer, presumably because the nutrients excreted by the copepods, e.g. ammonia (Ikeda 1985), were plentiful in spring and became limiting in summer. Thus, the addition experiment design offers another practical application of using bacterioplankton growth for accurately assaying bioavailability of mesozooplankton excretion.

The zooplankton concentrations required for detecting a measurable response of bacterioplankton during our experiments are rarely encountered in nature. Although any extrapolation should be considered with caution, we may use the experimental data and the copepod and appendicularian abundance at Stn L4 to estimate their potential impact on bacterioplankton in coastal waters. The species concentration at Stn L4 in
July, averaged over the $14 \mathrm{yr}$ of observation, is 230 (maximum 1600) Acartia $\mathrm{m}^{-3}$ and 82 (maximum 250) Calanus $\mathrm{m}^{-3}$. These 2 dominant copepod species could stimulate bacterioplankton growth by 0.9 and $2.2 \%$ respectively, $3 \%$ combined, and using maximum values up to $13 \%$. The average appendicularian concentration at Stn L4 in late spring/early summer is 120 (maximum 625) ind. $\mathrm{m}^{-3}$ (data available at www.pml. ac.uk/L4), and according to our experimental results, their grazing effect would decrease bacterial growth by $3 \%$ (maximum $14 \%$ ) ind $^{-1} \mathrm{l}^{-1}$. Consequently, appendicularian feeding could reduce bacterioplankton growth on average by a small margin of $0.4 \%$, with a maximum up to $9 \%$.

In summary, the present study shows the robustness of the bacterioplankton community structure. The presence of both crustacean and gelatinous mesozooplankton did not affect bacterioplankton composition but showed opposite effects on bacterioplankton growth; the dominant copepods may increase bacterioplankton growth in temperate coastal waters in summer by up to $13 \%$, and the appendicularians may reduce it by up to $9 \%$. However, we would caution that our findings of no significant changes in bacterial community composition, despite changes in community growth rates, require further confirmation using a set of more discriminating, species-specific probes.

Acknowledgements. We would like to thank Drs. Roger Harris, Xabier Irigoien and Pennie Lindeque for their help during the experimental part of the work and for constructive criticism and helpful comments on an earlier version of the manuscript. We are grateful for the opportunity to use the long-term observational database for Stn L4. We gratefully acknowledge the crews of local boats for collecting samples. The work of M.V.Z. was supported by the advanced research fellowship (NER/I/S/2000/00898) from the Natural Environment Research Council (NERC), UK The work of A.L.U. was supported by the project EURAPP (MAS3-CT98-0161) and the NERC Marine Productivity thematic programme (GST/02/2760).

\section{LITERATURE CITED}

Acuña JL, Deibel D, Morris CC (1996) Particle capture mechanism of the pelagic tunicate Oikopleura vanhoeffeni. Limnol Oceanogr 41:1800-1814

Amann RI, Krumholz L, Stahl DA (1990) Fluorescent-oligonucleotide probing of whole cells for determinative, phylogenetic, and environmental studies in microbiology. J Bacteriol 172:762-770

Bedo AW, Acuña JL, Robins D, Harris RP (1993) Grazing in the micron and the sub-micron particle size range: the case of Oikopleura dioica (Appendicularia). Bull Mar Sci 53:2-14

del Giorgio PA, Gasol JM, Vaque D, Mura P, Agusti S, Duarte CM (1996) Bacterioplankton community structure: protists control net production and the propoportion of active bacteria in a coastal marine community. Limnol Oceanogr 41 1169-1179 
Ducklow H (2000) Bacterial production and biomass in the oceans. In: Kirchman D (ed) Microbial ecology of the oceans. John Wiley \& Sons, New York, p 85-120

Fenaux R, Gorsky G (1985) Nouvelle technique d'elevage des appendiculaires. Rapp Comm Int Mer Medit 29:291-292

Fuchs BM, Glöckner FO, Wulf J, Amann R (2000a) Unlabeled helper oligonucleotides increase the in situ accessibility to 16S rRNA of fluorescently labeled oligonucleotide probes. Appl Environ Microbiol 66:3603-3607

Fuchs BM, Zubkov MV, Sahm K, Burkill PH, Amann R (2000b) Changes in community composition during dilution cultures of marine bacterioplankton as assessed by flow cytometric and molecular biological techniques. Environ Microbiol 2:191-202

Fuhrman JA (1999) Marine viruses and their biogeochemical and ecological effects. Nature 399:541-548

Glöckner FO, Amann R, Alfreider A, Pernthaler J, Psenner R, Trebesius K, Schleifer KH (1996) An in situ hybridization protocol for detection and identification of planktonic bacteria. Syst Appl Microbiol 19:403-406

Glöckner FO, Fuchs BM, Amann R (1999) Bacterioplankton composition in lakes and oceans: a first comparison based on fluorescence in situ hybridization. Appl Environ Microbiol 65:3721-3726

Hygum BH, Petersen JW, Sondergaard M (1997) Dissolved organic carbon released by zooplankton grazing activity - a high-quality substrate pool for bacteria. J Plankton Res 19:97-111

Ikeda T (1985) Metabolic rates of epipelagic marine zooplankton as a function of body-mass and temperature. Mar Biol 85:1-11

Jurgens K, Arndt H, Rothhaupt KO (1994) Zooplanktonmediated changes of bacterial community structure. Microb Ecol 27:27-42

Jurgens K, Pernthaler J, Schalla S, Amann R (1999) Morphological and compositional changes in a planktonic bacterial community in response to enhanced protozoan grazing. Appl Environ Microbiol 65:1241-1250

Katechakis A, Stibor H, Sommer U, Hansen T (2002) Changes in the phytoplankton community and microbial food web of Blanes Bay (Catalan Sea, NW Mediterranean) under prolonged grazing pressure by doliolids (Tunicata), cladocerans or copepods (Crustacea). Mar Ecol Prog Ser 234: $55-69$

King KR, Hollibaugh JT, Azam F (1980) Predator-prey interactions between the larvacean Oikopleura dioica and bacterioplankton in enclosed water columns. Mar Biol 56: 49-57

Kolber ZS, Plumley FG, Lang AS, Beatty JT and 6 others (2001) Contribution of aerobic photoheterotrophic bacteria to the carbon cycle in the ocean. Science 292: 2492-2495

Koshikawa H, Harada S, Watanabe M, Sato K, Akehata K (1996) Relative contribution of bacterial and photosynthetic production to metazooplankton as carbon sources. J Plankton Res 18:2269-2281

Koshikawa H, Harada S, Watanabe M, Kogure K and 5 others (1999) Influence of plankton community structure on the contribution of bacterial production to metazooplankton in a coastal mesocosm. Mar Ecol Prog Ser 186:31-42

Langenheder S, Jurgens K (2001) Regulation of bacterial biomass and community structure by metazoan and protozoan predation. Limnol Oceanogr 46:121-134

Maar M, Nielsen TG, Richardson K, Christaki U, Hansen OS, Zervoudaki S, Christou ED (2002) Spatial and temporal variability of food web structure during the spring bloom in the Skagerrak. Mar Ecol Prog Ser 239:11-29

Manz W, Amann R, Ludwig W, Vancanneyt M, Schleifer KH (1996) Application of a suite of 16S rRNA-specific oligonucleotide probes designed to investigate bacteria of the phylum Cytophaga-Flavobacter-Bacteroides in the natural environment. Microbiology 142:1097-1106

Marie D, Partensky F, Jacquet S, Vaulot D (1997) Enumeration and cell cycle analysis of natural populations of marine picoplankton by flow cytometry using the nucleic acid stain SYBR Green I. Appl Environ Microbiol 63: 186-193

Moller EF, Nielsen TG (2001) Production of bacterial substrate by marine copepods: effect of phytoplankton biomass and cell size. J Plankton Res 23:527-536

Mullins TD, Britschgi TB, Krest RL, Giovannoni SJ (1995) Genetic comparisons reveal the same unknown bacterial lineages in Atlantic and Pacific bacterioplankton communities. Limnol Oceanogr 40:148-158

Pernthaler J, Posch T, Simek K, Vrba J, Amann R, Psenner R (1997) Contrasting bacterial strategies to coexist with a flagellate predator in an experimental microbial assemblage. Appl Environ Microbiol 63:596-601

Robertson B, Button D, Koch A (1998) Determination of the biomasses of small bacteria at low concentrations in a mixture of species with forward light scatter measurements by flow-cytometry. Appl Environ Microbiol 64:3900-3909

Roff JC, Turner JT, Webber MK, Hopcroft RR (1995) Bacterivory by tropical copepod nauplii-extent and possible significance. Aquat Microb Ecol 9:165-175

Roman MR, Ducklow HW, Fuhrman JA, Garside C, Glibert PM, Malone TC, McManus GB (1988) Production, consumption and nutrient cycling in a laboratory mesocosm. Mar Ecol Prog Ser 42:39-52

Simek K, Nedoma J, Pernthaler J, Posch T, Dolan JR (2002) Altering the balance between bacterial production and protistan bacterivory triggers shifts in freshwater bacterial community composition. Antonie Van Leeuwenhoek 81: 453-463

Simon M, Glöckner FO, Amann R (1999) Different community structure and temperature optima of heterotrophic picoplankton in various regions of the Southern Ocean. Aquat Microb Ecol 18:275-284

Sommer U, Stibor H (2002) Copepoda-Cladocera-Tunicata: the role of three major mesozooplankton groups in pelagic food webs. Ecol Res 17:161-174

Stahl DA, Amann R (1991) Development and application of nucleic acid probes. In: Stackebrandt E, Goodfellow M (eds) Nucleic acid techniques in bacterial systematics. John Wiley \& Sons, Chichester, p 205-248

Zubkov MV, Sleigh MA, Burkill PH, Leakey RJG (2000) Bacterial growth and grazing loss in contrasting areas of North and South Atlantic. J Plankton Res 22:685-711

Zubkov MV, Fuchs BM, Archer SD, Kiene RP, Amann R, Burkill PH (2001a) Linking the composition of bacterioplankton to rapid turnover of dissolved dimethylsulphoniopropionate in an algal bloom in the North Sea. Environ Microbiol 3:304-311

Zubkov MV, Fuchs BM, Burkill PH, Amann R (2001b) Comparison of cellular and biomass specific activities of dominant bacterioplankton groups in stratified waters of the Celtic Sea. Appl Environ Microbiol 67:5210-5218

Zubkov MV, Zollner E, Jurgens K (2001c) Digestion of bacterial macromolecules by a mixotrophic flagellate, Ochromonas sp., compared with that by two heterotrophic flagellates, Spumella pudica and Bodo saltans. Eur J Protistol 37:155-166

Submitted: July 26, 2002; Accepted: January 6, 2003

Proofs received from author(s): April 10, 2003 